\title{
Variability of fish diets between dry and flood periods in an arid zone floodplain river
}

\author{
S.R. Balcombe ${ }^{\text {AC }}$, S.E. Bunn ${ }^{\text {A }}$, F.J. McKenzie-Smith ${ }^{\text {A }}$, P.M. Davies ${ }^{B}$ \\ ${ }^{\text {A } C o o p e r a t i v e ~ R e s e a r c h ~ C e n t r e ~ f o r ~ F r e s h w a t e r ~ E c o l o g y, ~ C e n t r e ~ f o r ~ R i v e r i n e ~ L a n d s c a p e s, ~ F a c u l t y ~ o f ~}$ \\ Environmental Sciences, Griffith University, Nathan, Queensland, Australia 4111. \\ ${ }^{\mathrm{B}}$ Centre of Excellence in Natural Resource Management, The University of Western Australia, Albany, \\ Australia.
}

The fish assemblages of an arid zone floodplain river, Cooper Creek, were sampled during two dry periods in isolated waterholes and on the inundated floodplain during the early and late phase of a major flood event. Diets were described for nine native species and compared within and between dry and flood periods. In the dry season, when fish were restricted to waterholes, diets were characteristically simple with narrow diet breadths. Movement onto the floodplain during flooding clearly increased feeding opportunities, with greater diet breadths evident in all species. Despite obvious potential for terrestrial inputs, diets tended to be dominated by aquatic resources in both the waterholes and on the floodplain. Stomach fullness, however, varied little between dry season waterhole and floodplain samples. Fish appear to feed on potentially lower value resources such as detritus and calanoid copepods during the dry season, when waterholes are isolated and food resources are limited. They are then able to capitalize on the "boom" of aquatic production and more diverse food resources associated with episodic flood events.

Keywords: arid zone; fish diet; benthic algae, carbon sources; terrestrial inputs; floods

${ }^{\mathrm{C}}$ Author to whom correspondence should be addressed. Tel: +61 7 38757308; fax: +61 738757615 ;

email: s.balcombe@griffith.edu.au 


\section{INTRODUCTION}

Sources of organic carbon in river food webs are often thought to be driven largely by terrestrial sources arising from upstream processes or alternately, in floodplain rivers, from lateral exchange during flood events (Vannote et al., 1980; Junk et al., 1989). The role of autochthonous inputs into the food webs of large rivers in particular, has more recently been suggested to play a larger role in ecosystem function than was previously thought (Thorp \& Delong, 2002; Bunn et al,. 2003). This is especially so in temperate and tropical river-floodplain systems. In dryland or arid river systems, however, our knowledge of ecosystem dynamics is limited. Hence the sources of organic matter supporting the food webs and ultimately fish diets of dryland/arid river systems are largely unknown (Bunn et al., 2003).

Diet analysis can reveal important information on the food resources available to fish, particularly across seasons (Lowe-McConnell, 1975; Persson, 1983; Lobon-Cervia \& Rincon 1994). While some foods may represent the most energetically rich resource they may not always be accessible. For example higher quality prey may not be available all year round due to natural seasonal declines in these resources (LoweMcConnell, 1975; Persson, 1983) and in such instances fish may switch to poorer quality food. Bluegill sunfish, Lepomis macrochirus diets in spring were mainly composed of invertebrates with a subsequent switch to an algal dominated diet by the end of summer as macroinvertebrate numbers fell (Kitchell \& Windell, 1970). Similarly, in an Australian intermittent stream, Closs (1994) found that mountain galaxiids (Galaxias olidus) consumed greater amounts of terrestrial food sources when flow ceased during the summer due to the disappearance of drifting 
invertebrates. Hence, in variable environments, such as arid zone rivers, we would expect fish to exhibit high seasonal variation in food resources, particularly in relation to varying hydrology.

Cooper Creek is an Australian arid zone river that exists for much of the time as a series of isolated and turbid pools and dry channels. During unpredictable flood events these channels and waterholes become connected forming extensive inundated floodplains (Puckridge et al.,1998; Bunn et al., 2003). Although there have been some fisheries surveys throughout the catchment (Long \& Humphrey, 1997; Bailey \& Long 2001), ecological studies on the fish assemblages are sparse, apart from Arthington et al. (2005) and Puckridge (1999) and there are no published studies relating to the trophic ecology of the fish. In fact, quantitative descriptions of the diets of many Australian freshwater fishes, particularly in arid zones are limited (Pusey et al., 2004). Stable isotope analysis of food webs of disconnected waterholes in Cooper Creek are largely driven by aquatic production, despite high turbidities and the presence of large amounts of terrestrial carbon (Bunn et al., 2003). Furthermore, most of the biomass carbon of fish was derived from benthic rather than pelagic sources. We would expect, therefore, that fish diets would be dominated by benthic sources, rather than zooplankton and nekton.

In large floodplain rivers, terrestrial inputs into fish diets increase in importance as floods move on to the floodplains (e.g. The Flood pulse Concept; Junk et al., 1989). Cooper Creek has been described as a "boom and bust" ecology (Walker et al., 1997), with booms associated with floodplain inundation and increased aquatic resources. Hence, we would expect to find two main changes in diet when fish move on to the 
floodplain: First, an increased range of foods eaten and second, increased consumption of terrestrial compared with aquatic food items.

In this paper we test the following hypotheses:-

1. Aquatic food sources will be the major diet component of fish in dry season waterholes (Bunn et al., 2003)

2. In dry season waterholes, the major aquatic component of fish diets will be primarily benthic in origin, while pelagic sources will constitute a smaller component (Bunn et al., 2003)

3. Floodplain diets in the wet season will be more diverse and terrestrial food sources will constitute a greater volumetric proportion of the diet than in dry season waterholes (Walker et al., 1997; Puckridge et al., 1998; Junk et al. 1989)

\section{MATERIALS AND METHODS}

Cooper Creek is an Australian dryland river formed from the confluence of the Thomson and Barcoo Rivers in Western Queensland, terminating at Lake Eyre in the arid interior (Fig. 1). It is hydrologically one of the world's most variable rivers and is virtually unregulated (Puckridge et al., 1998 Knighton \& Nanson, 2001). Like many Australian dryland rivers, Cooper Creek consists of a series of anastomosing channels and waterholes that become joined during unpredictable flood events. The river system, however, generally exists as a series of disconnected turbid waterholes (Bunn et al., 2003). 
The Cooper Creek catchment has a semi-arid climate, with an average rainfall of less than 400mm per year (Anonymous, 1998). Based upon 50 years of records (19391988) the average discharge at Windorah is $3.3 \mathrm{ML} \mathrm{year}^{-1}$. With interannual rainfall being highly unpredictable, however, there have been extended periods of no flow and several high discharge flood events. The largest recorded flood event occurred in 1974 with more than 23 million ML discharged (Anonymous, 1998). Approximately $35 \%$ of the catchment consists of floodplain (Graetz, 1980; Gibling et al., 1998), hence, large floods can cover vast areas and take many weeks to travel down the extensive networks of channels and wetlands.

Fish were sampled in four dry season waterholes in July 1998 and in one of these (Murken waterhole) also in October 1998. Of the four waterholes, two were on Kyabra Creek and 2 were on the same Cooper Creek distributary near Windorah (Fig. 1). On the floodplain, fish were sampled from four locations within a $5 \mathrm{~km}$ radius of Windorah in Februray 2000 and four locations within a 10km radius of Windorah in March 2000 (Fig. 1). The early floodplain samples (February) were taken as the floodwaters were moving onto the floodplain and included the peak of the flood. The late flood samples (March) were collected as the floodwaters were receding from the floodplain. Apart from two small floods (March 1994 and February/March 1997) there was little flow in Cooper Creek between February 2000 and the previous last major floods in April 1990 and February 1991 (Bunn et al., 2003).

\section{Fish capture}

The fish examined in this study were captured as part of a broader food-web study. Fish were captured with a $30 \times 2 \mathrm{~m}$ beach seine with $12 \mathrm{~mm}$ mesh and a drag net $(2.5 \mathrm{X}$ 
1.1 wide, $2.2 \mathrm{~m}$ deep, $1 \mathrm{~mm}$ mesh). Other gear used included a fine meshed $(1 \mathrm{~mm})$ fyke net $1.5 \mathrm{~m}$ deep, $2 \mathrm{~m}$ wings, $6 \mathrm{~m}$ leader, depth $.85 \mathrm{~m}$, bait fish traps and a $250 \mu \mathrm{m} \mathrm{d}$ net and a $250 \mu \mathrm{m}$ plankton tow-net. All dry season fish caught in waterholes were captured with the beach seine, while the drag seine and beach seines were used on the floodplain during flooding. Where possible, only fish captured with active methods were used for dietary analysis. Fish captured using the fyke net (passive method) were added to increase sample sizes where needed.

Upon capture, fish were identified, anaesthetized and killed following immersion in benzocaine. Fish were put into plastic bags and placed into a freezer where they were stored until return to the laboratory for subsequent food-web analysis.

\section{Laboratory procedure}

Stomachs (digestive tracts) were removed for dietary analysis. For fish with a true stomach, such as spangled perch, Leiopetherapon unicolor (Günther), this was the oesophagus to stomach section. Fish without a true stomach, such as the central Australian catfish, Porochilus argenteus (Zietz), had the anterior half of their digestive tracts removed. Percent stomach fullness was estimated visually, then dissected and the contents placed onto a graph paper-lined petri dish. The relative volumetric contribution of individual dietary items was assessed with an indirect volumetric method (Hyslop, 1980; Balcombe, 2002). Food items were identified and squashed to a constant depth and scored by the area covered (no. of graph squares covered). Due to the low numbers of individuals caught for most species and large size ranges (see Table I) it was not possible to describe diets for different size classes. 
Consequently, diet volumes were converted to relative volumes per fish total length (TL) (Rozas \& La Salle, 1990) to allow comparisons of different sized fish. Lengthconverted points for each food item were summed together and expressed as a percentage of the total points for all fish examined for each sampling time.

Dietary items were identified to the lowest practical taxonomic level, usually to Family. Higher taxonomic resolution was often not possible due to partial digestion. Twenty-three different food categories were recognized (Table II).

\section{Diet description}

Frequency histograms were constructed for visual comparisons of diets based upon broad food groups where ecologically similar prey items where grouped. Eight of these categories were chosen: terrestrial fauna, aquatic dipterans, zooplankton, plant material, algae, detritus, other aquatic fauna, fish/decapod crustaceans. Dry season waterhole and floodplain diets were further compared for fish species that had been collected under both sets of conditions using non-metric multidimensional scaling. This multivariate procedure was based upon a Bray-Curtis similarity matrix generated from logarithmic transformed data of all diet classes based upon their relative proportions using Primer-E version 5 for Windows (Clarke \& Warwick, 2001). Oneway analysis of similarity (ANOSIM) was used to test for differences between fish diets in the dry and wet using the same Bray-Curtis similarity matrix. The SIMPER (similarity percentages) routine (Clarke \& Gorley, 2001) was used to identify the species contributing to any differences between dry and wet fish diets on the same similarity matrix used to generate the MDS plot. 
To demonstrate feeding specificity, Levins (1968) measure of niche breadth (B) was calculated with the formula: $\mathrm{B}=1 / \Sigma \mathrm{p}^{2}$, where $\mathrm{p}$ is the proportion of each prey group in the diet. Niche breadth ranges from 1 to the total number of available prey categories. A value 1 of represents a highly specific diet. As with all subsequent analysis, unidentified items were omitted. Niche breadth and diet overlap indices were calculated from the total number of food categories (23).

\section{RESULTS}

\section{General diet descriptions}

During the dry seasons when fish were restricted to isolated waterholes their diets were very simple, usually dominated by one food type only. This was especially notable in July 1998, with zooplankton the principal prey of five of the seven species of fish (Table II). Most of the food consumed by all fish in the waterholes was sourced via aquatic production. Apart from zooplankton, fish also fed upon algae and a range of aquatic insects, particularly hemipterans and detritus. Most of the zooplankton taxa consumed were calanoid copepods, which actually represented the only food consumed by Ambassis sp. and Macquaria sp. B in July (Table II). The only fish species with a diet dominated by terrestrial inputs was $M$. splendida tatei. In addition to the consumption of some aquatic insects and algae, this species fed chiefly upon terrestrial arthropods, many of which were flying insects (e.g. ants, wasps and dipterans). R. semoni and $P$. argenteus also fed on some terrestrial fauna, however, their diets were chiefly aquatic. 
Fish collected on the floodplain during the early flood phase had relatively broad diets, feeding on a variety of aquatic and terrestrial resources (Table III), the majority of which were aquatic. Apart from N. erebi with a diet comprised of almost $70 \%$ algae, most of the food resources consumed were invertebrates. These were aquatic dipterans, other aquatic fauna (largely coleopteran larvae), zooplankton and terrestrial fauna (Fig. 3). The dipterans were mostly chironomid larvae, while the zooplankton prey consisted chiefly of conchostracans and cladocerans (Table III). Terrestrial fauna were not consumed by all species, being a small part of the L. unicolor diet (20\%) and the major food group eaten by M. splendia tatei. These terrestrial foods were either isopods, scolopendridid centipedes, or a variety of alighting insects such as dipterans, hymenopterans and coleopterans.

In the latter phase of the Cooper Creek flood most fishes consumed a range of zooplankton, dipterans, crustaceans, fish and other aquatic fauna (Table III). The consumption of terrestrial arthropods was reduced with $M$. splendia tatei diet being composed of $31 \%$ terrestrial insects and L. unicolor tending to feed on larger aquatic fauna (Table III). In contrast to the early flood, conchostracans were no longer present in the diets, and the zooplankton component was comprised mostly of cladocerans and ostracods. Chironomid larvae and pupae were the main dipterans consumed, while the other main aquatic faunal group was mainly larval trichopterans (Table III). Greater than half of the diet of the introduced fish, Gambusia holbrooki, consisted of gastropods, while the planktivorous $R$. semoni also fed upon aquatic insect larvae, especially trichopterans. Two species whose diets contrasted with all other species were Scortum barcoo and N. erebi. The two juvenile S. barcoo were 
examined and these fed on a mix of plant material and a range of small aquatic fauna. The other larger members of this species fed exclusively on plant material, namely the aquatic fern Nardoo, Marsilea drummondii. Plant material was also a large component of the $N$. erebi diet, although it was algal material (> 70\% by volume). Terrestrial invertebrates were uncommon in the diets of all species, apart from $M$. splendida tatei during the late phase of the flood.

\section{Floodplain vs waterholes}

Fish collected on the floodplain during the summer flood consumed a broader range of food types compared to the fish in dry season waterholes as indicated by dominance of diets by one or two groups in the dry, with no such dominance in the wet periods (Fig. 2). This was also confirmed by larger diet breadth values in the wet than dry (Table IV). There was also a clear shift of fish diets in multidimensional space between the two contrasting hydrological conditions (Fig. 3). This shift was clearly in the same general direction for all fish species, with fish diets in the waterholes spreading out to the right along the horizontal axis, reflecting changes in food resource use on the floodplain. Floodplain fish consumed a variety of food types, such as dipterans, crustaceans, fish and other aquatic fauna. Of these food types, chironomid larvae, and a range of zooplankters, particularly ostracods, cladocerans and conchostracans were prominent in the diets of most fish. In the waterholes, zooplankton, particularly calanoid copepods, dominated the diets of most species. N. erebi diets contrasted with those of most other fish due to the high algal component on the floodplain and high detrital component in the waterholes. Wet and dry season diets were significantly different (ANOSIM: Global $\mathrm{R}=0.344, \mathrm{p}=0.001$ ). 
The multivariate shift from dry to wet season diets (Fig. 3) was due to the change in the proportions of six main food items between the two periods (Table V). The largest change in overall diet composition was due to the reduced consumption of calanoids and increased consumption of chironomids in the wet compared with the dry.

Diets in the waterholes and on the floodplain were, predominantly sourced via aquatic production while consumption of significant amounts of terrestrial matter under both hydrological conditions was mainly restricted to M. splendida tatei (Fig. 2). There was no particular pattern in stomach fullness for fish in relation to hydrological conditions (Table VI). Both in flood and dry, fish were able to maintain similar volumes of food in their guts independent of food sources.

\section{DISCUSSION}

Fish diets in Cooper Creek were temporally variable both within dry season waterholes and during summer flooding on the floodplain. Comparable studies are not available, although the diets of most fish conform broadly to those described for these same species in other regions (Bishop et al., 1980; Merrick \& Schmida, 1984; McDowall, 1996; Pusey et al., 2004). The diet composition of most fish suggests that the Cooper Creek fish assemblage is composed mainly of generalist carnivores, with the exception of S. barcoo and N. erebi. The latter tended to be either omnivorous as found by Bishop et al. (1980), while S. barcoo was herbivorous, apart from the two juveniles of the species examined, which were planktivorous. 
There tended to be little piscivory, with only Ambassis sp., L. unicolor and M. splendida tatei with fish in their stomachs. All piscivory occurred on the floodplain where all three species fed upon larval or juvenile $N$. erebi. Larval and juvenile $N$. erebi were abundant and numerically dominated the catches of the small meshed drag net. Hence, they probably represented an abundant and relatively easy resource for fish with a large enough gape to consume them. Herbivory within the assemblage was also generally low, apart from S. barcoo and N. erebi which both fed entirely on plant matter when conditions allowed especially in the latter phase of the flood when both algae and nardoo growth was well established.

The floodplain diets probably revealed the true preferences of these fish under favourable conditions. Larger individuals of $S$. barcoo fed only on nardoo and $N$. erebi on diatoms and filamentous algae. Planktivory was generally high, but temporally dependent. For example, R. semoni showed a marked decrease in zooplankton consumption, with a diet shift from $80 \%$ during the dry to $35 \%$ during flooding. This species is often planktivorous in dry season lowland waterbodies (Lieschke \& Closs, 1999) and this diet switch may indicate that in a resource rich environment, $R$. semoni can increase its energy intake by switching from zooplankton to larger bodied benthic prey such as small trichopteran larvae. The exotic $G$. holbrooki, a fish that also often feeds on zooplankton (Pen \& Potter, 1991; Balcombe, 1994; Stoffels \& Humphries, 2003), had a diet that was comprised of only $36 \%$ zooplankton (mainly small cladocerans). Their major prey were benthic fauna $(60 \%)$ that were chiefly gastropods, a result not published in Australia, suggesting an opportunistic change in foraging behaviour under inundated floodplain conditions. 
The dry season waterhole diets confirmed our first hypothesis that the fish assemblages in dry season waterholes are sustained by aquatic production. We also predicted that benthic sources would constitute a greater proportion of fish diets than pelagic sources in the dry (hypothesis 2). However, it is clear that zooplankton actually represents a more significant dietary source than suggested from previous isotope studies (Bunn et al., 2003). There are two possible explanations for this result. First, gven that isotope analysis reflects assimilated carbon, fish must derive a disproportionate contribution to the biomass carbon from opportunistic feeding on large benthic invertebrates such as Cherax and Macrobrachium. If so, then foods such as calanoids and detritus may actually represent plentiful interim food sources when larger-bodied macroinvertebrate abundances are low (Kitchell \& Windell, 1970; Lowe-McConnell, 1975; Persson, 1983). Such situations could arise during extended dry periods, either due to depressed benthic production or increased predation of macroinvertebrates as water levels fall and predator-prey interactions increase. An alternative explanation for the higher than expected zooplankton consumption is that the relative importance of pelagic and benthic production may change through time as a function of recent flow history. For example in channel flow pulses could lead to depressed benthic production by disrupting the formation of the productive algal bathtub rings (Bunn et al., 2003).

Floodplain diets were indeed more diverse than dry season diets (hypothesis 3), however, the expected increase in the importance of terrestrial food sources during flooding was not found. Although some opportunistic species such as L. unicolor and M. splendida tate $i$ were able to take advantage of terrestrial invertebrates in the water, there was a general absence of terrestrial inputs to the diets of the whole fish 
assemblage. Much of our knowledge on how fish use the floodplain during its inundation phase is largely speculative and based upon Amazonian systems where floodplains remain inundated for months and terrestrial inputs are thought to be the driving force behind secondary production (Junk et al., 1989). This model is not likely to be appropriate in arid river systems for a number of reasons. These systems often have little or no riparian vegetation (Velasco et al., 2003) and riparian plants in arid regions often produce litter with low nutritional quality (Francis \& Sheldon, 2002), potentially rendering this resource unpalatable to potential invertebrate consumers. Furthermore, shredder densities in these areas are often low (Ward et al., 1986; Martinez et al., 1998) and other pathways are thus more likely to have primacy in the breakdown of terrestrial matter.

The majority of the fish diets are likely to be sourced via aquatic primary production on the floodplain, through the consumption of algae, aquatic plants or animals feeding upon these primary sources such as zooplankton and chironomids. Seine net samples collected on the floodplain also suggested that the most prolific fish by abundance and biomass were $N$. erebi (S. Balcombe unpub. data) and their diets were largely algal. This represents a significant turnover of aquatic primary production on the floodplain that would ultimately be returned to the waterholes when water levels fell (Lewis et al., 2001). As such, Cooper Creek fish assemblages could be considered to be supported mainly by autochthonous algal production in waterholes and energy subsidies derived from, algal production on the floodplain when waters recede following flood (Lewis et al., 2001). 
Overland floods are important for the long-term persistence of fish assemblages in lowland rivers especially because they allow access to the floodplain (Humphries et al., 1999; King et al., 2003). These floods are important for a number of critical lifestages of a fish as inundated floodplains can provide a food rich environment for larval and juvenile fish, or a spawning ground for adult fish. Furthermore, the floodplain can also serve as a conduit for recolonization back into waterholes where the available fish species pool is restricted to a few available refugia (remnant waterholes), particularly if the time since last flow is protracted compared to average flow duration. While there was no direct evidence of spawning involved with this flood, late-stage larvae and juveniles were certainly present on the floodplain (S. Balcombe unpub. data) and they would have been able to take advantage of the foodrich floodplain. They could then be expected to transform this energy source into growth and perhaps an elevated survivorship compared to non-flood conditions (Puckridge et al., 2000). Other studies on the Cooper Creek waterholes have indicated that the food rich floodplain conditions do translate into high fish numbers within the waterholes after disconnection (Arthington et al., 2005). Thus floodplain inundation is likely to be essential for the long-term health of this fish assemblage. The ability of these fish to maintain stomach fullness and persist on poor food sources when Cooper Creek is reduced to isolated waterholes is an important feeding strategy given the unpredicatable flow patterns of this river. The retention of waterholes is particularly important as they represent reserves that sustain these fish assemblages during periods of "bust" (Morton et al., 1995). Given the sustained pressure for water resource development in dryland river environments, it is important to continue to investigate the links between floodplains and waterholes and how these links translate into fish resource use and ultimately, recruitment success. 


\section{ACKNOWLEDGEMENTS}

Fish were collected under Queensland Fisheries Permit :PRM00157K. The authors would also like to acknowledge improvements and suggestions made by Angela Arthington and Gerry Closs on an earlier version of the manuscript. Funding was provided by the Commonwealth of Australia through the Department of Environment and Heritage (Environmental Flows Initiative) and Land and Water Australia (National Riparian Lands Program). Support was also provided by the CRC for Freshwater Ecology.

\section{REFERENCES}

Anonymous (1998) Draft Water Management Plan for Cooper Creek - Information paper. Department of Natural resources, Queensland Australia. ISBN 07242 7278.

Arthington, A.H., Balcombe, S.R., Wilson, G.A., Thoms, M.C. \&Marshall J. (2005) Spatial and temporal variation in fish-assemblage structure in isolated waterholes during the 2001 dry season of an arid-zone floodplain river, cooper Creek, Australia. Marine and Freshwater Research 56, 25-35.

Bailey, V. \& Long, P. (2001) Wetland, Fish and Habitat Survey in the Lake Eyre Basin, Queensland: Final Report. Department of Natural Resources and Mines, Queensland, Australia. ISBN 0734517971 
Balcombe S.R. (1994) The role of interspecific competition in regulating the fish assemblages of Baddaginnie Creek. Unpubl. Honours thesis. Department of Zoology, LaTrobe University, Bundoora, Australia.

Balcombe, S.R. (2002) Resource use by Hypseleotris (Pisces: Gobiidae) in the littoral macrophytes of a floodplain billabong. Unpubl. PhD thesis. Department of Environmental Management and Ecology, LaTrobe University, Albury/Wodonga, Australia.

Bishop, K.A., Allen S.A., Pollard, D.A. \& Cook, M.J. (1980) Ecological studies of the fishes of the Alligator Rivers region, Northern territory, Part 3, pp 673-694. Office of the Supervising Scientist for the Alligator rivers Region, Canberra.

Bunn, S.E., Davies, P.M. \& Winning, M. (2003) Sources of organic carbon supporting the food web of an arid zone floodplain river. Freshwater Biology 48, 1-17.

Clark, K.R. \& Gorley, R.N. (2001) Primer v5: User Manual/Tutorial. Primer-E Plymouth.

Clarke, K.R. \& Warwick, R.M. (2001) Change in Marine Communities: An approach to Statistical Analysis and Interpretation. $2^{\text {nd }}$ edition. Primer-E Plymouth.

Closs, G.P. (1994) Feeding of Galaxias olidus (Günther)(Pisces : Galaxiidae) in an intermittent Australian stream. Australian Journal of Marine and Freshwater Research 45, 227-232.

Francis, C. \& Sheldon, F. (2002) River Red Gum (Eucalyptus camaldulensis Dehnh.) organic matter as a carbon source in the lower Darling River, Australia. Hydrobiologi, 481, 113-124.

Gibling, M.R., Nanson, G.C. \& Maroulis, J.C. (1998) Anastomosing river sedimentation in the channel country of central Australia. Sedimentology 45, 595-619. 
Graetz, R.D. (1980) The Potential Applications of LANDSAT Imagery to Land Resource Management in the Channel Country. CSIRO Divison of Land Resources Management, Perth, Western Australia. Technical Memorandum $80 / 2$.

Humphries, P., King, A.J., \&d Koehn, J.D. (1999) Fish, flows and floodplains: links between freshwater fishes and their environment in the Murray-Darling River system, Australia. Environmental Biology of Fishes 56, 129-51.

Hyslop, E.J. (1980) Stomach contents analysis - a review of methods and their application. Journal of Fish Biology 17: 411-429.

Junk, W.J., Bayley, P.B. \& Sparks, R.E. (1989) The flood pulse concept in riverfloodplain systems. In Proceedings of the international Large River Symposium. (Ed. D.P. Dodge) pp 110-127. Canadian Special Publication Fisheries and Aquatic Sciences 106, 110-127.

Kitchell, J.F. \& Windell, J.T. (1970) Nutritional value of algae to bluegill sunfish, Lepomis macrochirus. Copeia 1: 186-190.

King, A.J., Humphries, P., \& Lake, P.S. (2003). Fish recruitment on floodplains: the roles of patterns of flooding and life history characteristics. Canadian Journal of Fisheries and Aquatic Sciences 60, 773-86.

Knighton, A.D. \& Nanson, G.C. (2001) An event based approach to the hydrology of arid zone rivers in the Channel Country of Australia. Journal of Hydrology 254, 102-123.

Levins, R. (1968) Evolution in changing environments: some theoretical explorations. Princeton University Press, Princeton. 120pp.

Lewis, W.M., Jr., Hamilton, S.K., Rodríguez, M., Saunders, J.F., III. \& Lasi, M.A. (2001) Foodweb analysis of the Orinoco floodplain based on production 
estimates and stable isotope data. Journal of the North American Benthological Society 20, 241-254.

Lieschke, J.A. Closs G. P. (1999) Regulation of zooplankton composition and distribution by a zooplanktivorous fish in a shallow, eutrophic floodplain lake in south east Australia. Archiv fur Hydrobiologie 146: 397-412.

Lobon-Cervia, J. \& Rincon, P.A. (1994) Trophic ecology of red roach (Rutilus arcasii) in a seasonal stream; an example of detritivory as a feeding tactic. Freshwater Biology 32: 123-132.

Long, P. \& Humphery, V. (1997) Fisheries Study Lake Eyre Catchment, Thomson and Diamantina Drainages, information series Q197080, Department of Primary Industries Brisbane. ISSN 0727-6273.

Lowe-McConnell, R.H. (1975) Fish communities in tropical freshwaters. Longman, London.

Martinez, B., Velasco, J., Suarez, M.L. \& Vidal-Abarca, M.R. (1998). Benthic organic matter dynamics in an intermittent stream in South-East Spain. Archiv für Hydrobiologie 141, 303-320.

McDowall, R.M. (ed.) (1996) Freshwater fishes of south-eastern Australia. Reed Books, Sydney. 247 pp.

Merrick, J.R. \& Schmida, G.E. (1984) Australian freshwater fishes: biology and management. Griffin Press, Netley, South Australia. 409 pp.

Morton, S.R., Doherty, M.D. \& Barker, R.D. (1995) Natural Heritage Values of the Lake Eyre basin in South Australia: World Heritage Assessment. CSIRO Division of Wildlife and Ecology, Canberra. 
Pen, L.J. \& Potter, I.C. (1991) Reproduction, growth and diet of Gambusia holbrooki (Girard) in a temperate Australian river. Aquatic Conservation: Marine and Freshwater Ecosystems I, 159-172.

Persson, L. (1983) Food consumption and the significance of detritus and algae to intraspecific competition in roach Rutilis rutilis in a shallow eutrophic lake. Oikos 41: 118-125

Puckridge, J.T. (1999) The Role of Hydrology in the Ecology of Cooper Creek, Central Australia: Implications for the Flood Pulse Concept. PhD Thesis (The University of Adelaide: Adelaide, South Australia.)

Puckridge, J.T., Sheldon, F., Walker, K.F. \& Boulton, A.J. (1998) Flow variability and the ecology of arid zone rivers. Marine and Freshwater Research 49, 5572.

Puckridge, J.T., Walker, K.F. \& Costelloe, J.F. (2000) Hydrological persistence and the ecology of dryland rivers. Regulated Rivers: Research and Management 16, 385-402.

Pusey, B.J., Kennard, M.J. \& Arthington, A.H. (2004) Freshwater fishes of northeastern Australia. CSIRO Publishing, Collingwood, Victoria. 684pp.

Rozas, L.P. \& La Salle, M.W. (1990) A comparison of the diets of gulf killifish, Fundulus grandis Baird and Girard, entering and leaving a Mississippi brackish marsh. Estuaries 13, 332-336.

Stoffels, R.J. and Humphries, P. (2003) Ontogenetic variation in the diurnal food and habitat associations of an endemic and an exotic fish in floodplain ponds: consequences for niche partitioning. Environmental Biology of Fishes 66: 293305. 
Vannote, R.L., Minshall, G.W., Cummins, K.W., Sedell, J.R. \& Cushing, C.E. (1980) The river continuum concept. Canadian Journal of Fisheries and Aquatic Sciences 37, 130-137.

Velasco, J., Millan, A., Vidal-Abarca, M.R., Suarez, M.L., Guerrero, C. \& Ortega, M. (2003) Macrophytic, epipelic and epilithic primary production in a semiarid Mediterranean stream. Freshwater Biology 48, 1408-1420.

Walker, K.F., Puckridge, J.T. \& Blanch, S.J. (1997) Irrigation development on Cooper Creek, central Australia - prospects for a regulated economy in a boom-andbust ecology. Aquatic Conservation: Marine and freshwater Ecosystems 7, 6373.

Ward, J.V., Zimmermann, H.J. \& Cline, L.D. (1986) Lotic zoobenthos of the Colorado system. In The ecology of river systems. eds. B.R. Davies \& K.F. Walker, pp 403-423. Dr W. Junk Publishers, Dordrecht, The Netherlands. 


\section{TABLES}

Table I. Mean total length (mm) and (range) of fish examined for diet for each sampling occasion in Cooper Ck. *Note: one fish analyzed only.

\begin{tabular}{|c|c|c|c|c|}
\hline $\begin{array}{l}\text { Fish species } \\
\text { (common name) }\end{array}$ & $\begin{array}{l}\text { Early flood } \\
2000\end{array}$ & $\begin{array}{l}\text { Late flood } \\
2000\end{array}$ & $\begin{array}{l}\text { July dry } \\
1998\end{array}$ & $\begin{array}{l}\text { October dry } \\
1998\end{array}$ \\
\hline $\begin{array}{l}\text { Ambassis sp. } \\
\text { (Northwest glassfish) }\end{array}$ & $39.7(29-44)$ & $41(26-52)$ & $42.5(40-45)$ & N/A \\
\hline $\begin{array}{l}\text { Scortum barcoo Mitchell } \\
\text { (Barcoo grunter) }\end{array}$ & N/A & $119.7(40-155)$ & N/A & N/A \\
\hline $\begin{array}{l}\text { Gambusia holbrooki Baird \& Girard } \\
\text { (mosquitofish) }\end{array}$ & N/A & $25.4(15-35)$ & N/A & N/A \\
\hline $\begin{array}{l}\text { Hypseleotris sp. } \\
\text { (carp gudgeons) }\end{array}$ & $23.8(18-31)$ & $19.7(11-30)$ & N/A & N/A \\
\hline $\begin{array}{l}\text { Leiopotherapon unicolor Günther } \\
\text { (spangled perch) }\end{array}$ & $56.4(15-170)$ & $99.4(23-142)$ & $80.6(60-130)$ & $160^{*}$ \\
\hline Macquaria sp. B & & & & \\
\hline (Lake Eyre drainage golden perch) & $57.8(48-69)$ & $50 *$ & $74(45-130)$ & $145.8(55-260)$ \\
\hline $\begin{array}{l}\text { Melanotaenia splendida tatei Zietz } \\
\text { (desert rainbowfish) }\end{array}$ & $31.2(12-54)$ & $51.6(30-79)$ & $48.7(40-55)$ & $55^{*}$ \\
\hline $\begin{array}{l}\text { Nematolosa erebi Gunther } \\
\text { (bony bream) }\end{array}$ & $67.3(29-44)$ & $65.5(35-155)$ & $54.5(30-110)$ & $128(40-260)$ \\
\hline $\begin{array}{l}\text { Porochilus argenteus Zietz } \\
\text { (Central Australian catfish) }\end{array}$ & $133(116-165)$ & $96.7(30-185)$ & $122.3(70-180)$ & $156(140-170)$ \\
\hline $\begin{array}{l}\text { Retropinna semoni Steindachner } \\
\text { (Australian smelt) }\end{array}$ & N/A & $26.3(14-41)$ & $51.3(50-55)$ & N/A \\
\hline
\end{tabular}


Table II. Percentage dietary composition by volume for fish collected from four Cooper Ck. dry season waterholes in July (J) 1998, and one waterhole in October (O) 1998. Key: Amb $=$ Ambassis sp., $\mathrm{Gam}=$ Gambusia holbrooki, Lei $=$ Leiopetharapon unicolor, $\mathrm{Hyp}=$ Hypseleotris sp., Mac = Macquaria sp. B, Mel = Melanotaenia splendida tatei, $\mathrm{Nem}=$ Nematolosa erebi, Por $=$ Porochilus argenteus, Ret $=$ Retropinna semoni, $\mathrm{Sco}=$ Scortum barcoo $\mathrm{L}=$ Larvae, $\mathrm{P}=$ Pupae, $\mathrm{N}=$ Number of fish examined. Note: Due to the low numbers of fish collected from any one site in July 1998, it was necessary to pool all diets into a dry season July group. A visual inspection of diets at the four locations revealed very similar diets among locations for any particular species.

\begin{tabular}{|c|c|c|c|c|c|c|c|c|c|c|c|c|}
\hline species & $\mathrm{Amb}$ & Leio & Leio & Mac & Mac & Mel & Mel & Nem & Nem & Por & Por & Ret \\
\hline & $\mathrm{J}$ & $\mathrm{J}$ & $\mathrm{O}$ & $\mathrm{J}$ & $\mathrm{O}$ & $\mathrm{J}$ & $\mathrm{O}$ & $\mathrm{J}$ & $\mathrm{O}$ & $\mathrm{J}$ & $\mathrm{O}$ & $\mathrm{O}$ \\
\hline $\mathrm{N}$ & 10 & 11 & 1 & 5 & 13 & 9 & 1 & 19 & 12 & 15 & 10 & 4 \\
\hline Fish & - & - & - & - & - & - & - & - & - & - & - & - \\
\hline Crustacea & - & 4.8 & 100 & - & 49.3 & - & - & - & - & - & - & - \\
\hline Gastropododa & - & - & - & - & - & - & - & - & - & - & 27.2 & - \\
\hline detritus & - & - & - & - & 0.8 & - & - & 23.1 & 81.5 & 16.2 & 25.6 & - \\
\hline algae & - & - & - & - & - & 16.8 & - & 1.1 & 18.5 & 9.0 & - & - \\
\hline plant & - & - & - & - & - & - & - & 1.8 & - & - & - & - \\
\hline Rotifera & - & - & - & - & - & - & - & - & - & - & - & - \\
\hline Cyclopoida & - & - & - & - & - & - & - & - & - & - & - & - \\
\hline Calanoida & 100 & 52.3 & - & 100 & 3.7 & - & - & 74.0 & - & 9.8 & - & 77.8 \\
\hline Cladocera & - & - & - & - & - & 0.6 & - & - & - & 40.0 & 2.3 & - \\
\hline Ostracoda & - & - & - & - & - & 2.5 & - & - & - & 4.6 & - & - \\
\hline Conchostraca & - & - & - & - & - & - & - & - & - & - & - & - \\
\hline Culicinae (L) & - & - & - & - & - & - & - & - & - & - & - & - \\
\hline Chironomidae (L) & - & - & - & - & 1.0 & - & - & - & - & 18.1 & 12.5 & - \\
\hline Other diptera $(\mathrm{L})$ & - & - & - & - & 0.8 & - & - & - & - & - & - & - \\
\hline Diptera $(\mathrm{P})$ & - & - & - & - & - & - & - & - & - & - & - & - \\
\hline Coleoptera (L) & - & - & - & - & - & - & - & - & - & - & - & - \\
\hline Hemiptera & - & 34.8 & - & - & 35.6 & - & - & - & - & 2.3 & 2.5 & - \\
\hline Other aquatic insects & - & 8.1 & - & - & 8.8 & 2.5 & - & - & - & - & 7.5 & - \\
\hline Acarina & - & - & - & - & - & - & - & - & - & - & 2.3 & - \\
\hline
\end{tabular}




\begin{tabular}{|c|c|c|c|c|c|c|c|c|c|c|c|c|}
\hline Eggs & - & - & - & - & - & - & - & - & - & - & - & - \\
\hline Terrestrial insects & - & - & - & - & - & 67.4 & 100 & - & - & - & 2.2 & 22.2 \\
\hline Other terrestrial & - & - & - & - & - & 10.2 & - & - & - & - & 17.7 & - \\
\hline invertebrates & & & & & & & & & & & & \\
\hline
\end{tabular}


Table III. Percentage dietary composition by volume for fish collected during Februray/March floods in Cooper Ck. E denotes early flood samples, L denotes late flood samples. Key as per Table 2. *Denotes that a proportion of stomachs were from fish captured by passive methods (always less than $25 \%$ of total N). Note: Due to the low numbers of fish collected from any one site, it was necessary to pool the samples from four early flood sites into one group and the four late sites into one group. A visual inspection of the diets at the four locations revealed very similar diets among locations for any particular species at both times.

\begin{tabular}{|c|c|c|c|c|c|c|c|c|c|c|c|c|c|c|c|c|c|c|}
\hline & species & $\mathrm{Amb}$ & Amb & Sco & Gam & Lei & Lei & Нyp & Нyp & Mac & Mac & Mel & Mel & Nem & Nem & Por & Por & Ret \\
\hline & & $\mathrm{E}$ & $\mathrm{L}$ & $\mathrm{L}$ & $\mathrm{L}$ & $\mathrm{E}$ & $\mathrm{L}$ & $\mathrm{E}$ & $\mathrm{L}$ & $\mathrm{E}$ & $\mathrm{L}$ & $\mathrm{E}$ & $\mathrm{L}$ & $\mathrm{E}$ & $\mathrm{L}$ & $\mathrm{E}$ & $\mathrm{L}$ & $\mathrm{L}$ \\
\hline & $\mathrm{N}$ & $10^{*}$ & 7 & 10 & 9 & $22 *$ & $10 *$ & $6^{*}$ & $18^{*}$ & 5 & 1 & 9 & 22 & $38 *$ & $29 *$ & 4 & 13 & 16 \\
\hline Fish & & - & 47.4 & - & - & 5.4 & 53.4 & - & - & - & - & - & 1.1 & - & - & - & - & - \\
\hline Crustacea & & - & - & - & - & - & 22.3 & - & - & - & - & - & - & - & - & - & - & - \\
\hline Gastropododa & & - & - & 0.7 & 53.6 & - & 22.1 & - & - & - & - & - & 7.4 & - & - & - & - & - \\
\hline detritus & & - & - & - & - & - & - & - & - & - & - & - & - & 5.5 & 0.7 & - & - & - \\
\hline algae & & - & - & - & - & - & - & - & - & 0.5 & - & - & - & 72.7 & 72.9 & - & - & - \\
\hline plant & & - & - & 95.2 & - & - & - & - & - & - & - & - & 0.7 & - & 9.7 & - & 0.3 & - \\
\hline Rotifera & & - & - & - & - & - & - & - & 1.7 & - & - & - & - & - & 2.1 & - & - & - \\
\hline Cyclopoida & & - & 5.5 & - & - & - & - & - & 37.7 & - & - & 25.9 & - & 1.3 & 1.2 & - & - & 31.8 \\
\hline Calanoida & & 7.2 & 4.8 & - & - & 4.0 & - & 24.5 & - & 0.6 & - & - & - & 10.9 & 0.8 & - & - & - \\
\hline Cladocera & & 10.8 & 0.3 & - & 36.3 & 5.2 & - & 34.2 & - & - & - & - & - & 5.9 & 0.4 & - & 4.3 & 3.5 \\
\hline
\end{tabular}




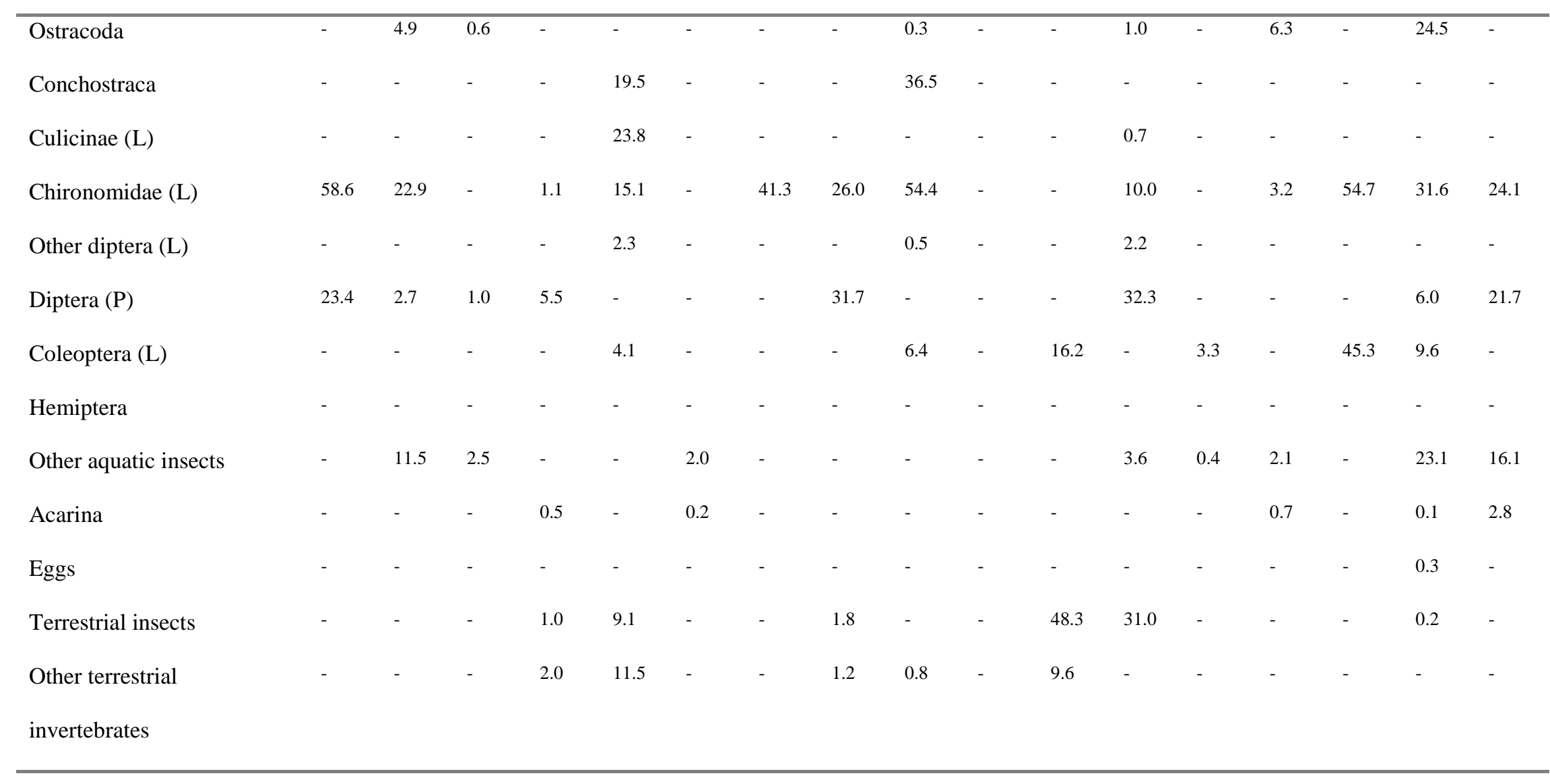


Table IV. Diet breadth measures and number of stomachs examined for flood and dry season diets in Cooper Ck.

\begin{tabular}{|c|c|c|c|c|c|c|}
\hline Fish species & July dry & $\begin{array}{l}\text { October } \\
\text { dry }\end{array}$ & Early flood & Late flood & All flood & All dry \\
\hline Ambassis sp. & $1(10)$ & - & $2.41(10)$ & $3.35(7)$ & $3.66(17)$ & $1(10)$ \\
\hline G. holbrooki & - & - & - & $2.36(9)$ & $2.36(9)$ & - \\
\hline Hypseleotris sp. & - & - & $2.88(6)$ & $3.22(18)$ & 5.06 & - \\
\hline L. unicolor & $2.48(11)$ & - & $6.74(22)$ & $2.61(10)$ & $7.65(32)$ & $2.54(12)$ \\
\hline Macquaria sp. B & $1(5)$ & $2.64(13)$ & $2.31(5)$ & - & $2.31(6)$ & $2.29(18)$ \\
\hline M. splendida tatei & $2.03(9)$ & & $2.98(9)$ & $3.45(22)$ & $3.66(31)$ & $2(10)$ \\
\hline N. erebi & $1.66(19)$ & $1.43(12)$ & $1.83(38)$ & $1.83(29)$ & $1.83(67)$ & $2.39(31)$ \\
\hline$P$. argenteus & $4.18(15)$ & $5.13(10)$ & $1.98(3)$ & $4.39(13)$ & $4.32(16)$ & $5.63(25)$ \\
\hline R. semoni & $1.53(4)$ & - & - & $4.27(16)$ & $4.27(16)$ & $1.53(20)$ \\
\hline S. barcoo & - & - & - & $1.10(10)$ & $1.10(10)$ & - \\
\hline
\end{tabular}

Table V. Species contributions to the dissimilarity between dry and wet diets, based upon MDS plot (Fig. 3). Note: average dissimilarity between groups $=92 \%$ (from SIMPER)

\begin{tabular}{lllll}
\hline Diet items & $\begin{array}{l}\text { Average } \\
\text { abundance }\end{array}$ & $\begin{array}{l}\text { Average } \\
\text { abundance } \\
\text { (wet) }\end{array}$ & $\begin{array}{l}\text { Average } \\
\text { dissimilarity }\end{array}$ & \\
& 0.49 & 0.01 & & \\
\hline Calanoids & 0.02 & 0.26 & 1.44 & 25.9 \\
Chironomids & 0.13 & 0.03 & 1.36 & 13.3 \\
Terrestrial insects & 0.05 & 0.11 & 0.64 & 7.8 \\
Algae & 0.00 & 0.1 & 0.92 & 7.4 \\
Other dipterans & 0.00 & 0.00 & 0.56 & 5.5 \\
Detritus & 0.10 & & & 5.2 \\
\hline
\end{tabular}


Table VI. Mean stomach fullness $( \pm$ s.e) for fish captured in floods and dry habitats in Cooper Ck. Note: Values only calculated for $\mathrm{N}>3$ for a species on any sampling occasion.

\begin{tabular}{lllllll}
\hline Fish species & July dry & October & Early flood & Late flood & All flood & All dry \\
& & & & & \\
& & & & & \\
& & & & & & \\
\hline Ambassis sp. & $0.73(0.1)$ & - & $0.79(0.11)$ & $0.6(0.13)$ & $0.71(0.08)$ & $0.73(0.1)$ \\
G. holbrooki & - & - & - & $0.58(0.11)$ & $0.58(0.11)$ & - \\
Hypseleotris sp. & - & - & $0.32(0.14)$ & $0.59(0.09)$ & $0.53(0.08)$ & - \\
L. unicolor & $0.74(0.13)$ & - & $0.64(0.10)$ & $0.59(0.11)$ & $0.62(0.07)$ & $0.68(0.13)$ \\
Macquaria sp. B & $0.9(0.1)$ & $0.41(0.11)$ & $0.96(0.04)$ & - & $0.8(0.16)$ & $0.54(0.1)$ \\
M. splendida tatei & $0.81(0.08)$ & & $0.58(0.10)$ & $0.64(0.07)$ & $0.62(0.05)$ & $0.74(0.1)$ \\
N. erebi & $0.62(0.08)$ & $0.67(0.12)$ & $0.6(0.07)$ & $0.72(0.07)$ & $0.65(0.05)$ & $0.64(0.07)$ \\
P. argenteus & $0.71(0.10)$ & $0.57(0.15)$ & $0.83(0.17)$ & $0.4(0.08)$ & $0.48(0.08)$ & $0.65(0.08)$ \\
R. semoni & $1(0)$ & - & - & $0.73(0.06)$ & $0.73(0.06)$ & $1(0)$ \\
S. barcoo & - & - & - & $0.7(0.1)$ & $0.7(0.1)$ & - \\
\hline
\end{tabular}




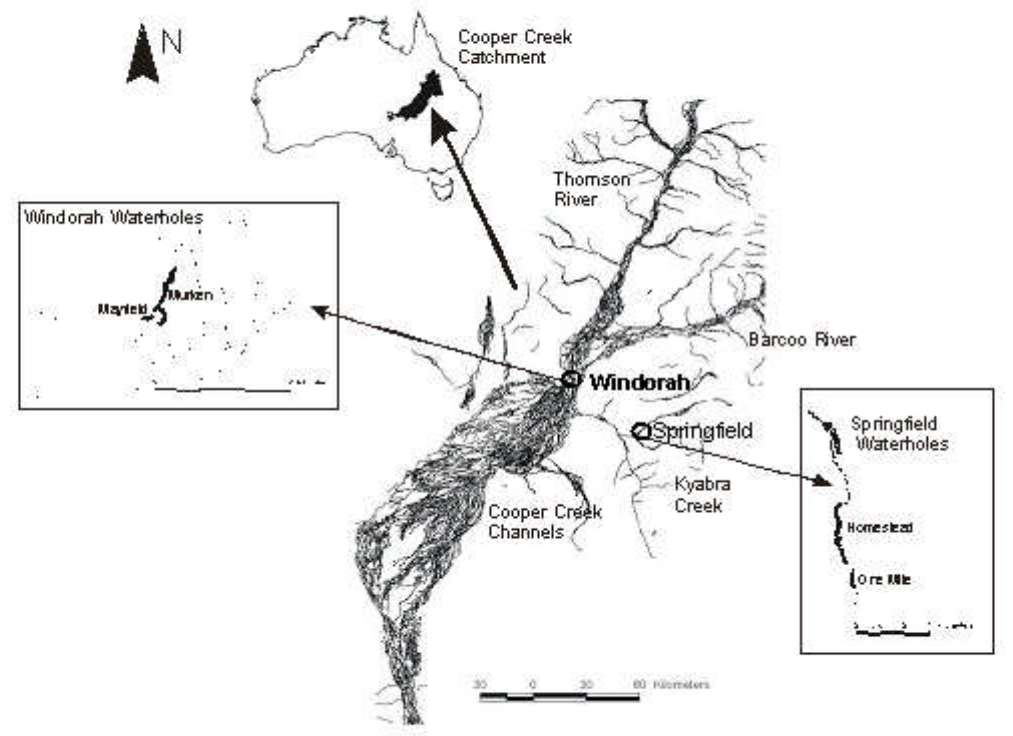




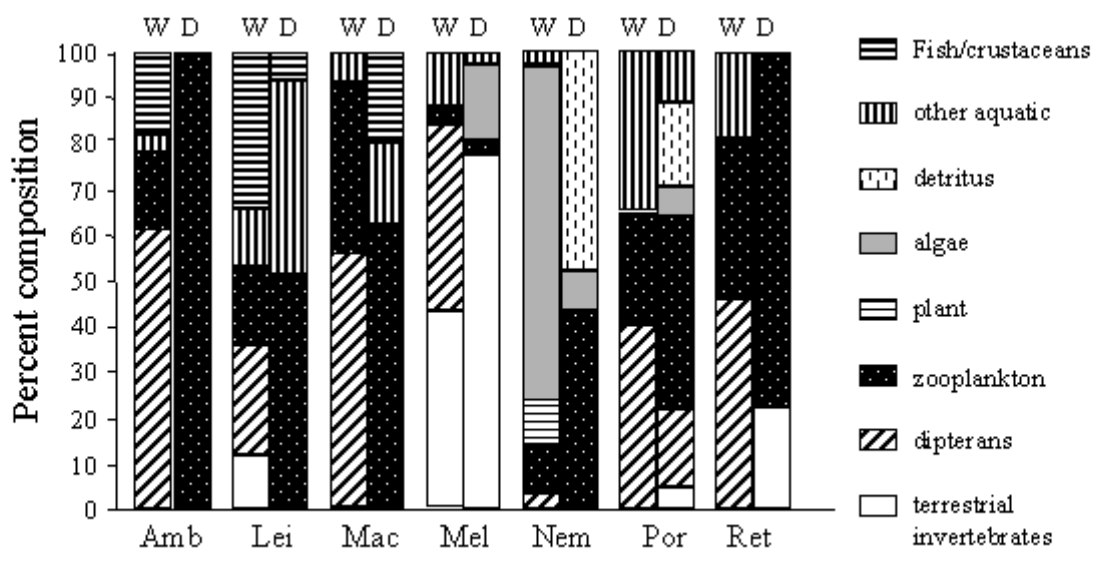




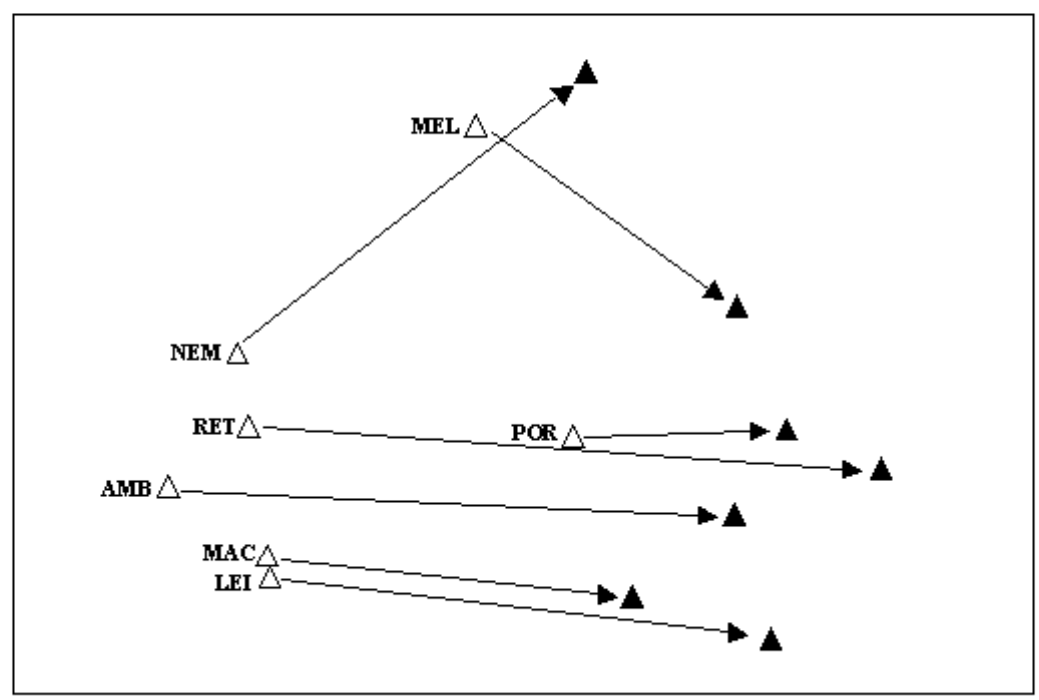

